Journal of Social Sciences 1 (3): 172-177, 2005

ISSN 1549-3652

(c) 2005 Science Publications

\title{
Changes in the Conscious Mind in Applying Technology for Growing Rice At the Chee River Basin in Northeastern of Thailand
}

\author{
${ }^{1}$ Pramuan Sati, ${ }_{1}^{1}$ Jaruwan Dhamawat, ${ }^{2}$ Preecha Pratepha and ${ }^{3}$ Sampan Rittidech \\ ${ }^{1}$ Faculty of Humanities and Social Science, Mahasarakham University, Thailand \\ ${ }^{2}$ Faculty of Technology, Mahasarakham University, Thailand \\ ${ }^{3}$ Faculty of Engineering, Mahasarakham University, Thailand
}

\begin{abstract}
A study of Local technology for rice Farming at the time of crisis of communities along the Chee river basin, which was aimed at investigating the patterns of the Local technology , that farmers used to solve the problems of growing rice when facing a crisis and conditions related to the use of Local technology for rice. The researcher used the principles of field methodology for gathering data. The survey study was carried out in 25 villages in the Chee river basin. The study focused on the conditions of crises in 3 villages: the crisis of saline soil in Baan Doo Yai, Tambon Muang Plia, Amphur Baan Phai, Khon Kaen province; the crisis of flooding in Baan Kui Chuak, Tambon Nong Bua, Amphur Kosum Phisai, Mahasarkram province and the crisis of drought in Baan Don Klong, Amphur Muang, Yasothon province. This study focused on investigation of the methods, which were used for finding solutions to the farmer's problems.The results of the study found that the crisis features were created naturally. In addition, they had an effect on the country's development scheme which has led to modernization while ignoring the culture of the communities and the management of natural resources. Therefore, the rice yield was uncertain. One way of solving the problems was by making an adjustment to the rice farming calendar that conformed to the changes in nature and utilizing that knowledge by observing the changes that might occur. This included the application of rice farming methodology. The farmers sought modern technology in their use of farm equipment and tools, biotechnology and social technology to solve the problems. Applying these factors and conditions in utilizing different technologies, depending on the nature of the eco-cultural aspects. The indication of the use of technology was that the farmers possessed farm equipment and tools for rice farming. On the other hand, the use of manual labor and animals was decreased. The farmers were able to bring forth both one crop and two-crops a year and the yield was increased. Also it was found that, not only did the farmers grow rice, but they did other activities for a living. However, the main activity of the farmers was growing rice. The importance of growing rice was based upon natural factors, laborers and household economy. Making a living for the farmers was based upon the overlapping condition of dependence on the marketing. The patterns of production were: growing rice, livestock, employment, handicraft and other supplementary needs of occupations. A group of cooperatives for production was established for bargaining prices in the marketplace. The strength of the communities was created through the rice farming culture as a bridge to relationship. This was to protect, develop and return the ecological system to the communities in a sustainable, developmental manner. The most importance thing was to give dignity back to the farmers. Trends in the use of the Local technology for rice Farming of communities along the Chee river basin seems to be decreasing as the farmers increasingly bring appropriate-modern technology for use in growing rice.
\end{abstract}

Key words: Conscious mind, applying technology, growing rice, chee river basin, northeastern of Thailand

\section{INTRODUCTION}

The natural characteristics of the land in theChee river basins induced many racial groups to settle in the area. The settlers included ethnic groups of I-saan people (Thai-Loas), Thai-Cambodian and ThaiChinese. The ethnic groups of people residing in the Chee river basin had their folklore rooted in making a living in agriculture, every household growing rice, cropping land, raising domestic animals and weaving. The main agricultural activity was for household consumption, not for sales. Growing rice was an important activity that all family members had to join together to help. So the farmers' field products were related to nature rather than social relations ${ }^{[1]}$.

Corresponding Author: Pramuan Sati, Faculty of Humanities and Social Sciences, Mahasarakham University, Thailand, Tel. +66-43-754361 Fax. +66-43-222064 


\section{THE CRISIS OF GROWING RICE IN CHEE RIVER BASIN}

The conditions of growing rice in the chee river basin: The principal occupation of the farmers in the Chee River basin was agricultural ${ }^{[2]}$. The farmers produced both one crop and two-crops a year. In the past, the farmers' communities in the Chee River basin were generous to each other at all levels. The household family, relatives and the community had close relations to the ecological system. They were inter-dependent and showed generosity to others. At present, the farmers have to support themselves in most areas of making a living and using of farm equipment and tools for growing rice. However, the farmers still lack in developing productive technology. The technological transfer was inefficient. The application of natural resources for production and consumption was not on an equilibrium state. Moreover, the farmers often faced the crises of saline soil, flooding and sustainable droughts. Therefore, neither economically nor socially were, the farmers able to stand on their own legs. The rice yield per Rai was low. The farmers had to promptly seek a means to solve these problems by increasing the efficiency of their own productive methods in order to increase their farm product. First, manual labor and energy were fully utilized in the agricultural process. Second, a change of rice seed and application of fertilizers and chemical substances for fertilizing plants and pest control ${ }^{[3]}$. However, the process of solving the above mentioned problems by these two-means was by the application of new technology in rice farming which created problems in production cost and the deterioration of the soil. This included the creation of substances that might affect human beings and ecological system. Both these situations, that of nature and the development scheme were rarely focused on in the interest of the economy. This affected the ecological system and led to the crisis of decreasing the rice yield. However, the development of technology in growing rice did not depend only on the geological state. It also depended on the development of society and culture in the community. The farmers in the Chee River basin had a means of growing rice and a lifestyle that conformed to the ecological system in each crisis as follows:

The crisis of growing rice in saline soil areas: Saline soil spread out in most provincial areas of I-saan and there were 17.8 million Rais of saline soil. The occurrence of saline soil was caused by deforestation which caused the uncovering of soil and underground water. Salt solution was absorbed and brought up to the ground surface. Since the salt was based under the ground at a shallow level the soil surface was inappropriate for growing rice. The saline soil severely affected rice farming causing the rice plants not to grow well and be stunted. Leaves became pale and eventually dried up. The farmers solved this problem by using animal manure and rice husks spread on the paddy field. Composed manure was included in order for the soil to be fertilized. Although, this approach could not solve the problem completely and permanently, it was a way that the farmers could solve the problem to some degree. In the saline soil areas, the farmers grew rice the same way other people did in other areas, in general. The only thing was that the farmers in this area would always have to improve the soil so that they would be able to grow rice. In years where there was a small amount of rainfall, the farmers could not grow rice since there was too much salt dissolved on surface of the topsoil. Generally, the farmers growing rice in the saline soil areas would do a one year crop only, this was rainfall rice farming using the rice seed Sweet Mali 105 and the sticky rice seed Kor Khor 6. These two rice seeds were better for growing in the saline soil areas than other rice seed. The old traditional rice seed was not used at this time (Fig. 1 and 2).

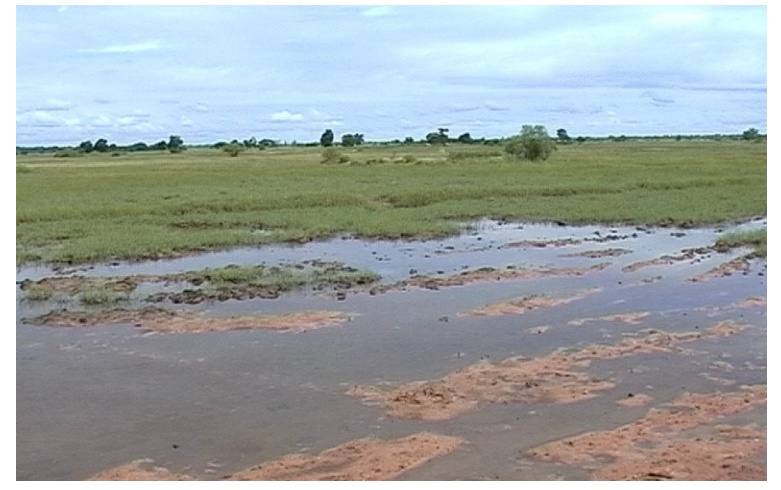

Fig. 1: The crisis of growing rice in saline soil areas

The farmer's life in saline soil areas - the farmers did other activities to earn a living supplementing the income earned from growing rice like the farmers in Baan Doo Yai, Amphur Baan Phai, Khon Kaen province. Women made a living by doing silk Mudmi and a handloom weaving. Men made a living by raising domestic animals and seeking employment in the industrial factories. Some farmers produced salt for sale in dry season that conformed to the physical characteristics of the area and they would return to growing rice again in wet season when the natural climate was more supportive.

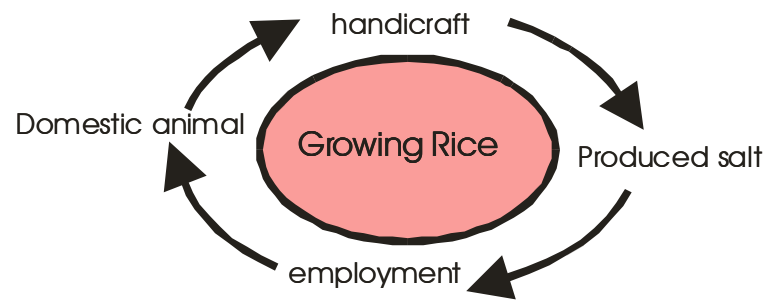

Fig. 2: The patterns of produced in saline soil areas 
The crisis of growing rice in flooding areas: The situations of flooding occur in the I-saan region, since its terrain is a flat-pan area ${ }^{[4]}$. In addition, the influence of the southwestern rainstorms from the Indian Ocean bring much more rainfall and cause floods rapidly as those that often occurred in 1978, 1980 and 1997. And in 2000 there was a flood again after the Department of Energy Extension and Development, Ministry of Technology Sciences and Environments started the construction of a weir for keeping water in the Chee River. It was a project of spreading the water from the Chee River according to the Khong-Chee-Moon Project. This caused severe flooding and water remained standing for longer than usual, because the irrigation weir blocked the water in the Chee River and the water gate was higher than the level of the rice field areas. In 2002 there was a severe flood in Isaan,especially in the Chee river basin. It damaged and brought severe loss to the farmers. The farmers could not make plans for growing rice as they had previously done in the past. Growing rice during the crisis of flooding has a bigger impact on the ecological system than from other crises. The farmers have recently become aware of the risk that rapid flooding has on the grown-rice plants and which can lead to severe loss of their rice plants and eventually the death of the plants. This causes increased production costs. However, the farmers in saline soil areas have still gained an advantage. Apart from growing rice in wet season as usual, the farmers grow rice on irrigation systems throughout the year. The farmers growing rice during the crisis of flooding brought more technology like farm equipment and tools to be used in all steps of rice farming more so than in other crises. Apart from growing rice for household consumption, the farmers grew rice for sale as in the phenomenon of growing rice in the crisis of flooding at Baan Kui Chuak, Tambon Nong Bua, Amphur Kosum Phisai, Mahasarakram province. So we learned that, the farmers made a living at the risk of growing rice throughout the year. The farmers always made preparations for the use of the farm equipment and tools for rice farming. There were two patterns of rice farming - first, the farmers would not grow rice in the wet season, instead they would do other activities to earn income for their families. Then they would return to growing rice again when the cultivation season had passed. Second, the farmers would take a risk on growing rice as usual in the wet season, as they believed that, if there was not much flooding they could be able to control and manage it. And if they could not manage it, definitely they would accept the loss. Then the farmers would return to their rice farming again after the crisis had passed. The rice seed types that met the market requirements were: Pratum Thani $1 \&$ 2, Chainat 2, Suphan Buri 60, Sweet Mali 105 and Kor Khor 6 (Fig. 3 and 4).

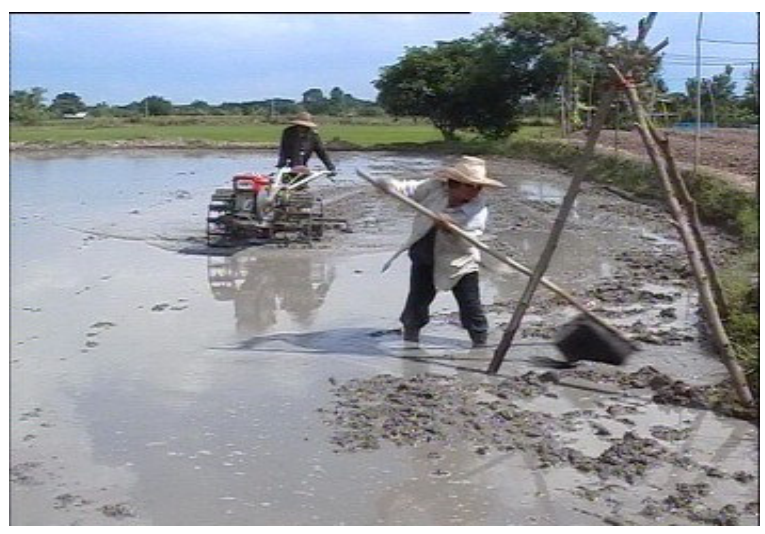

Fig. 3: The crisis of growing rice in flooding areas

The farmer's life in the risky crisis of sustainable is flooding in addition to growing rice, the farmers made a living by carrying out handloom weaving and planting in their home gardens. Farm products from these activities were sold for additional income to their families. They did these things as their supplementary occupation. Some families earned more income from the home gardens than the income that was earned from growing rice. But there was a limitation of using chemical fertilizers in the plantation in the home gardens, because some farmers were allergic to the chemicals, they could not do the plantation any longer.

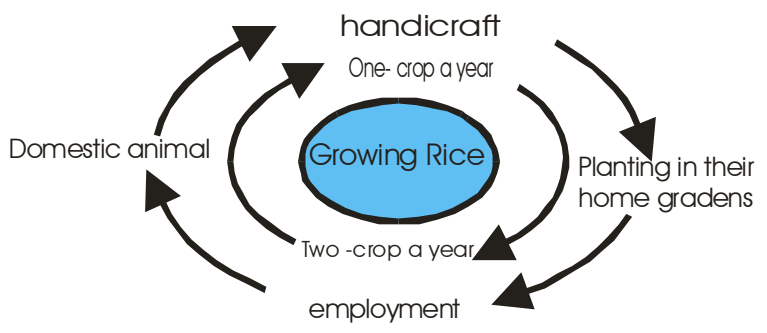

Fig. 4: The patterns of produced in flooding areas

The crisis of growing rice in drought areas: The problem of drought was caused by the occurrence of unseasonable rainfall for a long period of time. The farmers utilized the natural resources too much and deforestation occurred because there was not appropriate management. This resulted in severe deterioration of the natural resources. The natural resources were utilized for economic purposes without any thought of restoration. This affected the ecological system of the forest, soil and water, which led to the crisis of a change in the environment. This affected the paddy fields outside the irrigation area, or the area where the farmers grew rice in wet season. There were no water resources which could be used during the crisis of the drought. This included a lack of water for household consumption during dry season, especially in the areas far away from the water resources. However, in the irrigation zone itself, if more areas of plantation 
were spread out, the quantity of water which was stored in the weirs was inadequate for the plantation. In addition, if the water also was used for other activities it would lead to the scarcity of water. And if the forest trees were cut, then the topsoil surface would be dry because of no water absorption. If no water was held under the ground it might eventually lead to the crisis of severe drought. A survey carried out by the Parliament Commission of Agriculture and Cooperatives in 2003; found that 4,808 out of the 8,137 villages in the Chee river area faced a crisis of severe drought. The droughts brought severe hardships to the farmers in these areas. The farmers growing rice as a principal occupation which depended on the natural rainfall would choose a specific-agricultural area where there was the least risk of a lack of water in the wet season. A short-life-rice seed was selected for growing in their fields. It was a risk to grow rice during the crisis of drought as it severely affected the growth of plants. If the crisis of drought occurred and the farmers were unable to solve it, it was necessary that they would have to accept the fact that the plants would die. But in the years that there was enough rainfall for the growth of plants there would be a larger yield product. This phenomenon happened in the Yasothon province where the farmers loved to do organic agriculture. The yield and quality of rice was good and adequate for consumers both in the country and in foreign countries.

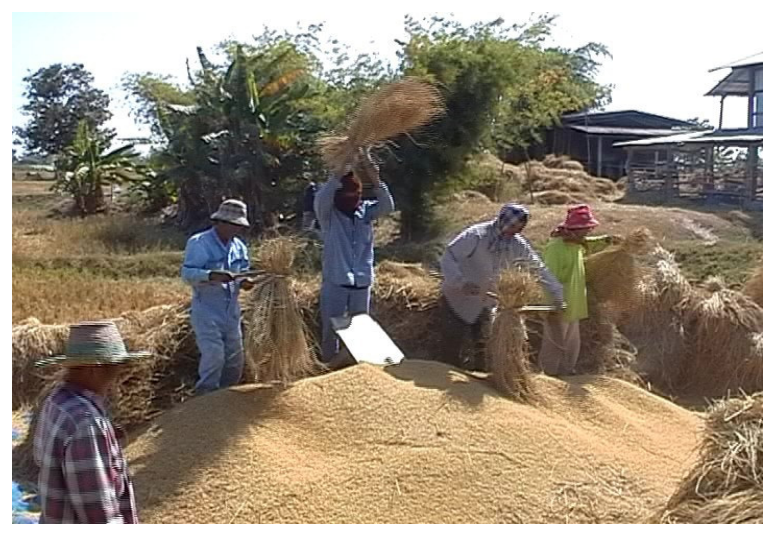

Fig. 5: The crisis of growing rice in drought areas

For security, the farmers in the drought areas grew rice during the wet season to make sure that they would have enough rice for consumption throughout the year. In addition, the farmers made a living on other activities as a supplementary occupation. For example, the farmers in Baan Don Klong, Tambon Nong Rua, Amphur Muang, Yasothon province made a living on handicraft weaving of the rice boxes, raising cattle and carrying out integrated farming. Such supplementary occupations made a lot of profit for the communities. Although the farmers faced this type of crisis frequently, they still were determined to continue making a living by growing rice. In parallel, they tried very hard to find ways to compensate for the problems of growing rice in the form of supplemental activities such as raising livestock and other alternative types of employment.

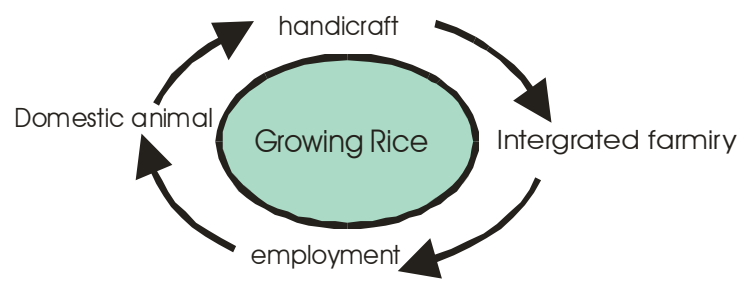

Fig. 6: The patterns of produced in drought areas

Changes in production goals: In the past, the farmers in the Chee river basin mainly produced farm products for their household's consumption. They used traditional knowledge in growing rice. They solved various problems on their own with accumulative experience from the ages. They utilized local-traditional farm equipment and technology that could be sought in the communities including deploying self-labor, relatives and neighbors in which there should conform to farming calendar, nature and tradition (Table 1 and 2).

Now the lifestyle of the farmers in the Chee river basin has been changed due to the crises of nature and the crises that were created by man. This included the change of a wave of globalization. They now face various problems such as household economy, the high cost of living and the desire of materialism. Because of this production goals have been changed from production only for self-consumption to production for both self-consumption and for sale. This has resulted in social and cultural changes in the farmer's lifestyle. The occurrence of such a phenomenon was seen clearly when the Thai government implemented the National Economic and Social Development Master Plan.This direction of development to modernization has concretely affected the farmers in two areas: 1) the farmers have no place to stand in society, 2) the farmers' culture leads to the past and it is an obstacle to further development. The future of the farmers on such a pathway presents a choice for them as being employed only as laborers, or only as capitalists ${ }^{[5]}$. However, the changes in the production process of the farmers that emerged seen in 2 features: the changes created through the evolution of society rather than by government development plans and the changes created by social value and needs. The sudden change in the production process created new values that pushed the farmers towards eagerness to possess new technology. Some farmers agreed to borrow money for purchasing technology although they were aware that selling farm products would not be enough to pay off the debt. Nevertheless, they still decided to go into debt. Some farmers had to sell off their cows and buffalos, 
Table 1: The old rice-farming calendar

\begin{tabular}{|c|c|c|c|c|c|c|c|c|c|c|c|c|}
\hline Months & Feb 3 & Mar 4 & Apr 5 & May 6 & June 7 & July 8 & Aug 9 & Sep10 & Oct 11 & Nov 12 & Dec 1 & Jan 2 \\
\hline Tradition. & $\begin{array}{l}\text { Boon } \\
\text { Khao } \\
\text { jee }\end{array}$ & $\begin{array}{l}\text { Boon } \\
\text { Pawet }\end{array}$ & $\begin{array}{l}\text { Boon } \\
\text { Song } \\
\text { kran }\end{array}$ & $\begin{array}{l}\text { Boon } \\
\text { Bung } \\
\text { Fy }\end{array}$ & $\begin{array}{l}\text { Boon } \\
\text { Sum } \\
\text { ha }\end{array}$ & $\begin{array}{l}\text { Boon } \\
\text { Khao } \\
\text { punsa }\end{array}$ & $\begin{array}{l}\text { Boon } \\
\text { Padub } \\
\text { din }\end{array}$ & $\begin{array}{l}\text { Boon } \\
\text { Khao } \\
\text { Sag }\end{array}$ & $\begin{array}{l}\text { Boon } \\
\text { Oxpun } \\
\mathrm{Sa}\end{array}$ & $\begin{array}{l}\text { Boon } \\
\text { Katin }\end{array}$ & $\begin{array}{l}\text { Boon } \\
\text { Khao } \\
\text { Gum }\end{array}$ & $\begin{array}{l}\text { Boon } \\
\text { Kron } \\
\text { laan }\end{array}$ \\
\hline Activity & $\begin{array}{l}\text { manure } \\
\text { on } \\
\text { dry } \\
\text { ground }\end{array}$ & & & plow & $\begin{array}{l}\text { Rice } \\
\text { Begins } \\
\text { to } \\
\text { grow }\end{array}$ & & $\begin{array}{l}\text { Rice } \\
\text { to } \\
\text { grow }\end{array}$ & & & $\begin{array}{l}\text { Rice } \\
\text { ripens }\end{array}$ & $\begin{array}{l}\text { Rice } \\
\text { Cut } \\
\text { and } \\
\text { thresh }\end{array}$ & $\begin{array}{l}\text { Rice } \\
\text { Keep }\end{array}$ \\
\hline
\end{tabular}

Table 2: The new rice-farming calendar

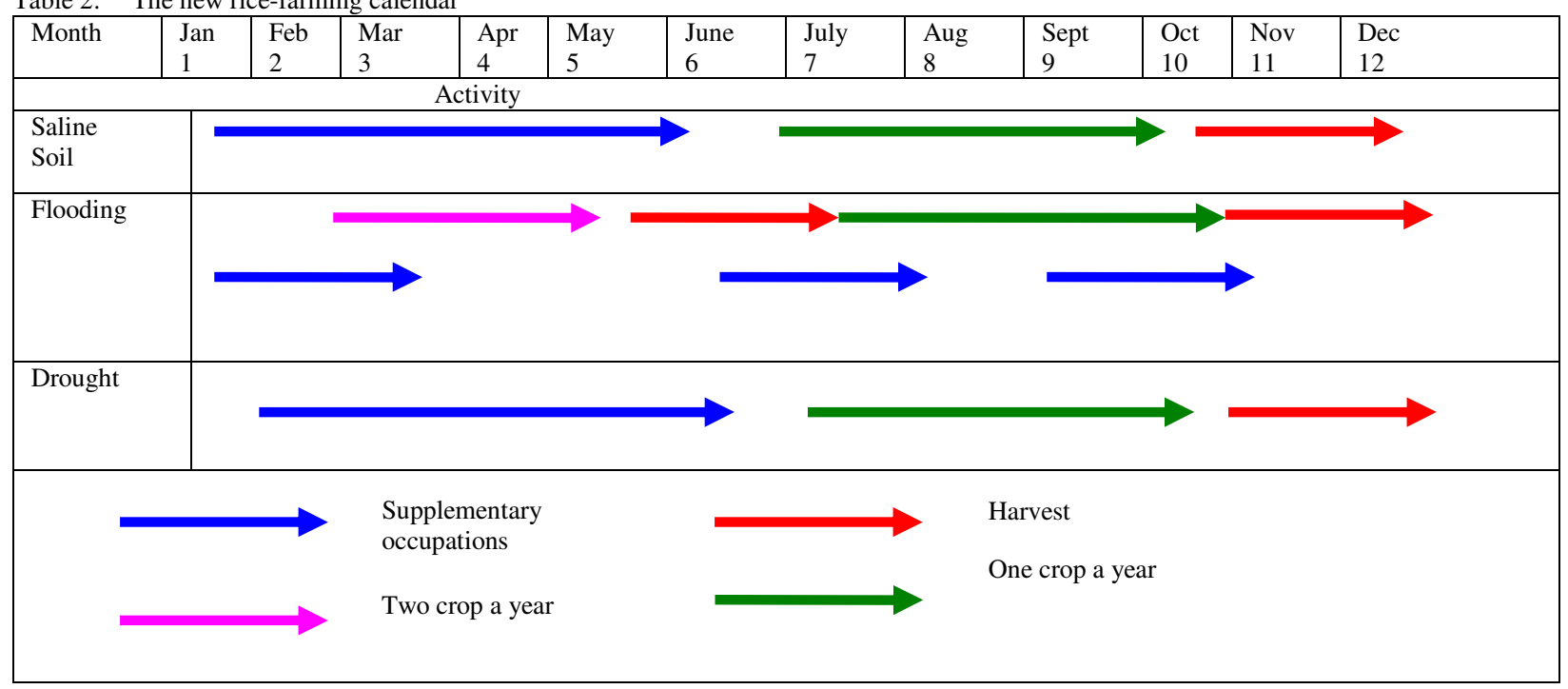

just to buy a plough machine. Another factor which induced the farmers to decide to make use of new technology was the conditions of the change in nature such as the climate and unseasonable rainfall, or scarce rainfall with a small amount of rainwater for a short period of time. The farmers had to quickly make preparations to cultivate their land. If the farmers still used animals for plowing land, they would be unable to grow rice in time. Or if the surface of the soil became sticky due to a covering of weeds, it would be difficult to have the buffalo plow the land. Instead, the farmers had to purchase a plough machine. Also the ricefarming calendar had to be changed accordingly. They might make two- or three-crops a year instead of one crop a year. The farmers used new technology to accelerate cultivation and they tried to increase farm production in order to have enough products to meet the commercial needs.

The changes in production goals demonstrated the innovation of the new technology for rice farming as a step forward in response to the needs of the modern world society with its increased population and limited natural resources. So it is necessary for new technology to be innovated efficiently and developed effectively.
This is necessary in order to conform to the needs of the farmers in our modern time. These changes in production goals have impacted the economy, society, culture, ecology and the environment. The disadvantage of the change from production for consuming to production for sales resulted in loss of the traditional rice seed from the farmers. The multi-rice genetic erosion did not help with the problem of improving the rice seed in the long term. The traditional rice seed were more beneficial to the seed culture even though they gave a lower yield per Rai and were not popular for eating. However, they were still more necessary to the farmers in I-saan because the multi-rice seed contributed to the geographical conditions in this region which had as terrain configurations - high and low land differences. The traditional rice seed had better properties to be used to propagate other seed and improve the seeding process as the researchers (agronomists) needed ${ }^{[6]}$. However, the development of farm production in response to meeting the economic requirements without paying attention to the development of society, culture and the environment was not a real way or means to develop the farmer's quality of life. 
Adjustment of identity of the farmers: Chatthip Nathasupa noticed that the application of new technology, which was created outside the agroeconomic boundary of the farmers, has an impact on the farmers' workforce in 2 areas: 1) the farmers' workforce for a special-specific production will be dominated gradually across the boundary to the domain of capitalism. When the farmer's production collapses, the farmers have to merge themselves into the labor market and become as goods. The farmers would not be able to define self-production against their daily lives and the natural resources, or 2) the farmers would take new technology on trial by reducing the workforce, but keeping the production goal of the family that is just to meet the needs of consumption ${ }^{[5]}$. At present, the farmers' adjustments for self-survival in the Chee river basin are intrinsically connected to the natural, economic and social conditions which they cannot avoid. Although, adjustments were made to guarantee their livelihood which was basic, this has increased their economic-consciousness in the modern application. The pattern of the farmers' adjustments have focused foremost on the application of time and the budget of the family. On the one hand, the use of labor was to support the producing of the product or the services for survival. On the other hand, the family was able to employ workers to support the production of sales in the marketing system, which was the pattern of the family's economic structure. This resulted in pushing female laborers into the labor market in order to respond to the labor demands in the form of creating added value. The farmers' adjustment to depending on the marketing system contributed to the need for monetary exchange in the daily life of the farmers. It resulted in a dependence on the monetary system because money is the indicator of the security of life and the family's survival ${ }^{[7]}$. The change in the culture of the marketing system not only uses money for more communication, but also uses the natural resources in a way that directly threatens the farmers' security in local communities. The external wave of the changes could also create an impact on the identity or the subjectivecultural of the farmers. The subsequent result is that the farmers' culture becomes an insignificant commoditization in the labor market of the industrial sector and the marketing mechanism could significantly make society, at all levels, a material-cultural process and possibly be lost from the communities that owned the cultural symbols ${ }^{[8]}$.

\section{CONCLUSION}

At present, the conceptual image of the farmers in the Chee river basin has been changed both in positive and negative ways. The farmers have become slaves to new technology and received stimulation to use it even through they really do not know how to use it properly. This technology depends on factors brought from outside. Therefore, farmers have restricted their ability to utilize traditional knowledge for growing rice. They have been dominated by external factors and new rice growing processes. The farmers have lost their dignity and identity totally. But the changes in identity of the farmers are positive as they are not viewed as growing rice only. The individual farmer is involved in many activities, in parallel. In order to insure the survival of their livelihood the farmers must have their own capital and be able to freely manage the sales of their products by themselves. They must learn how to use appropriate technology for growing rice and they should be well informed on how to evaluate the geographical conditions. Another thing that the farmers have to do along with growing rice is to engage in supplementary activities such as raising livestock, starting garden plantations, doing integrated farming, growing mulberry trees and silk worms, cotton weaving and setting up groups of farmers to handle production. This is to establish bargain prices in the marketing system and to strengthen the communities by means of cultural relations in order to develop and maintain the security of their communities and return the ecological system to the communities as well. The most important matter is that of returning the dignity of the farmers back to its original point, that of growing rice and if the farmers need to grow rice in different concentrations, that will be determined by the principal-productive factors of nature, labor and family economy.

\section{ACKNOWLEDGEMENTS}

The authors express their sincere appreciation for all of the support provided.

\section{REFERENCES}

1. Dhamawat, J., 2000. The relationship between lifestyle and ways of sufficient production for I-saan people: Case study of communities along the Chee river basin. Faculty of Humanities and Social Sciences, Mahasarakarm Universitiy.

2. Kunuratana, P. et al., 1988. A study of environment and use of swampy forest in central Moon river basin. Khon Kaen: Institute for Research and Development, Khon Kaen University.

3. Siamvala, A. and W.N. Ranong, 1990. Knowledge of rice. Bangkok, Institute for Research and Development.

4. Suratanakaweekul, P., 1997. Agricultural cultures of Thai Society: historical dimension. Bangkok, Institute for Research and Development, Kasetsart Univerisity.

5. Narksupha, C. et al., 1998. Theory and economic concept of farmer communities. Bangkok, Amarin Printing and Publishing.

6. Pratepha, P. et al., 1995. Research in the collection and investigation on features of agriculture and gene of local sticky rice in the northeastern region. Mahasarakarm: Mahasarakarm University.

7. Suwanartchariya, C., 2003. Non-formal economy in the Chee river basin: history of expansion of communities along the Chee river basin. pp: 238-257 Mahasarakarm: Academic Document for Seminar, Mahasarakarm University.

8. Hwankaew, S., 2002. Worldwide-narrow mind toward choose and ways of Thais in globalization age. Bangkok, Ruankaew Publishing. 